\title{
Profil Berpikir Kritis Siswa Dalam Memecahkan Masalah Matematika Open Ended Ditinjau Dari Gaya Kognitif Field Dependent-Independent
}

\author{
Oleh: \\ Afifah Surya Rufaidah ${ }^{1 *}$, Ismail ${ }^{l}$ \\ ${ }^{1}$ Jurusan Matematika FMIPA Universitas Negeri Surabaya \\ 1afifahrufaidah16@gmail.com
}

\begin{abstract}
Abstrak - Tujuan penelitian ini adalah mendeskripsikan profil berpikir kritis siswa dengan gaya kognitif field dependent-independent dalam memecahkan masalah open ended matematika. Metode yang digunakan adalah deskriptif kualitatif yang akan memberikan gambaran profil berpikir kritis siswa dengan gaya kognitif field dependent-independent dalam memecahkan masalah matematika open ended. Subjek yang digunakan pada penelitian ini adalah 2 siswa kelas IX dengan rincian masing-masing 1 siswa gaya kognitif field dependent $(\mathrm{FD})$ dan field independent $(\mathrm{FI})$. Teknik pengumpulan data dilakukan dengan cara tes gaya kognitif GEFT, tes pemecahan masalah matematika (TPMOE) dan wawancara. Data yang diperoleh dianalisis pada setiap tahap pemecahan masalah berdasarkan kriteria berpikir kritis Jacob dan Sam. Setelah diteliti, hasil menunjukkan profil berpikir dua subjek mengenai pemahaman masalah relatif identik. Kedua subjek melaksanakan indikator klarifikasi, namun subjek FD salah dalam menghubungkan antar bagian saat menyelesaikan menggunakan cara ke II. Kedua subjek memenuhi indikator asesmen dan strategi pada saat langkah menyusun rencana. Subjek FI dan FD memberikan alasan yang masuk akal terkait dengan strategi yang dipakai, memilih informasi yang terkait dengan pemecahan masalah, serta dapat memberikan alasan yang tepat pada setiap langkah. Kedua subjek juga dapat memprediksi hasil dari langkah pengerjaan yang telah dibuat. Saat tahap melaksanakan rencana, kedua subjek menyelesaikan permasalahan sesuai dengan tahap yang telah direncanakan serta bisa membuat konklusi secara tepat. Kedua subjek memeriksa kembali langkah yang telah dilakukan pada langkah memeriksa kembali. Subjek FD kurang teliti saat memahami masalah sehingga berakibat menggunakan cara yang salah pada cara II.
\end{abstract}

Kata Kunci : Berpikir kritis, pemecahan masalah, field dependent-independent.

Abstract - The aims of this research is to describe the critical thinking profile of students with field dependent-independent cognitive styles in solving open ended mathematics problems. The method in this research is descriptive qualitative which will produce descriptive data in the form of a description of the critical thinking profile of students with dependent-independent field cognitive style in solving open ended mathematical problems. The subjects were 2 students on $9^{\text {th }}$ grade junior high school with the details of each student is, the first student with field dependent (FD) cognitive style and the second student with field independent (FI). Data collection techniques were carried out by means of the GEFT cognitive style test, mathematical problem solving test (TPMOE) and interviews. Data were analyzed based on Jacob and Sam's critical thinking criteria at each step of Polya's problem solving. The results showed the profile of thinking of the two subjects at the same stage on understanding the problem. Both subjects carry out clarification indicators, but the subject FD is wrong in connecting between parts when completing using method II. In the steps of devising a plan the two subjects carry out all the assessment indicators and strategies. Both subjects provide logical reasons related to the strategy used, the selection of relevant information, and can provide the right reasons at each step. Both subjects can also predict the results of the steps that have been made. In the steps of carrying out the plan, the two subjects solve the problem in accordance with the steps that have been planned and can make conclusions correctly. In the step of looking back, the two students evaluate the steps that have been taken. The FD subject was not too careful when understanding the problem so that he use the wrong method on the II method.

Keywords: critical thinking, problem solving, field dependent-independent. 


\section{Pendahuluan}

Matematika mempunyai peran penting dalam menata pemikiran manusia. Ketika seseorang terbiasa mempelajari matematika maka akan terbentuk pemikiran yang kritis, kreatif, logis dan sistematis. Mengingat pentingnya peran matematika dalam menata pemikiran manusia, penguasaan matematika perlu diperkuat demi terbentuknya generasi penerus dengan pemikiran yang sistematis, logis, kritis, dan kreatif. Semakin tajam seseorang dalam membuat keputusan maka akan semakin tajam pula orang tersebut dalam menganalisis suatu permasalahan. Berpikir kritis merupakan kemampuan dalam menggunakan keterampilan berpikir untuk menafsirkan, menganalisis, mengevaluasi, serta membuat suatu keputusan yang didasari bukti yang tujuannya adalah terciptanya keputusan yang logis.

Di Indonesia kemampuan berpikir kritis masih kurang. Pada pembelajaran sains dan matematika siswa di Indonesia cenderung pada kemampuan menghafal. Menurut Rizal (dalam Setiawan, 2019) pada tahun 2018 rangking PISA Indonesia turun dari urutan ke-71 menjadi 77, PISA mengukur kemampuan literasi yang didalamnya bukan hanya sekedar membaca namun juga memahami teks untuk memecahkan masalah kontekstual yang dapat dilatih dengan berpikir kritis. Suatu kemampuan untuk menafsirkan, menganalisis, mengevaluasi, serta membuat keputusan yang didasari dengan bukti disebut berpikir kritis (Prihartini, dkk, 2018). Diperlukan berpikir kritis dalam menyelesaikan masalah matematika karena dalam menyelesaikan masalah siswa menafsir, menganalisis, mengevaluasi, serta membuat keputusan yang didasari dengan informasi yang ada.

Masalah merupakan suatu situasi dimana seseorang belum memiliki prosedur penyelesaian sebelumnya. Sesuai dengan pendapat Siswono (2008) yang mengartikan masalah sebagai pertanyaan atau situasi yang dihadapi seseorang atau kelompok ketika tidak memiliki algoritma/prosedur untuk mendapatkan solusi.

Pemecahan masalah merupakan salah satu cara untuk meningkatkan kemampuan berpikir kritis. Cahyono (2017) berpendapat bahwa dari kegiatan siswa dalam memecahkan masalah dapat dilihat dengan profil berpikir kritis siswa. Untuk menyelesaikan masalah, siswa membutuhkan keterampilan berpikir kritis. Hal tersebut sesuai dengan Johnson (dalam Rasiman \& Pramasdyahsari 2014) yang menjelaskan bahwa langkah pengambilan keputusan, pemecahan masalah, penemuan ilmiah, dan menganalisis asumsi diatur dengan pemikiran yang kritis. Oleh sebab itu, langkah seseorang dalam memecahkan suatu masalah menjadi tolak ukur berpikir kritis siswa.

Menurut NCTM (dalam Cahyani dan Ririn, 2016) dalam pembelajaran matematika terdapat lima kemampuan utama proses berpikir salah satunya yakni kemampuan pemecahan masalah. Berkaitan dengan pemecahan masalah, Polya (2004) menyarankan empat langkah dalam memecahkan masalah, yaitu (1) memahami masalah, (2) membuat rencana, (3) melaksanakan rencana, dan (4) memeriksa kembali. Kriteria berpikir kritis Jacob dan Sam dapat dihubungkan dengan langkah pemecahan masalah Polya seperti pada tabel di bawah ini.

Tabel 1. Hubungan Langkah Pemecahan Masalah Polya dengan Kriteria Berpikir Kritis Jacob

\begin{tabular}{|l|l|}
\hline \multicolumn{1}{|c|}{$\begin{array}{c}\text { Langkah Pemecahan } \\
\text { Masalah }\end{array}$} & Kriteria Berpikir Kritis \\
\hline Memahami masalah & Klarifikasi \\
\hline Menyusun rencana & Asesmen \\
\cline { 2 - 3 } & Strategi \\
\hline Melaksanakan rencana & Inferensi \\
\hline Memeriksa kembali & Strategi \\
\hline
\end{tabular}

Kriteria berpikir kritis strategi terdapat pada langkah pemecahan masalah menyusun rencana serta memeriksa kembali. Kriteria berpikir kritis strategis terdapat pada dua langkah pemecahan masalah dikarenakan kriteria berpikir kritis strategi dibutuhkan ketika menyusun langkah penyelesaian untuk mendapatkan solusi yang tepat serta dibutuhkan strategi dalam memprediksi hasil dan mengevaluasi langkah yang mungkin.

Penggunaan masalah open ended akan memberi peluang siswa membuat hubungan antar gagasan yang diperlukan dan berpikir secara mendalam untuk memecahkan suatu masalah (Al-Absi, 2013). Pemberian masalah berjenis open ended dapat mengembangkan daya kritis siswa. Menurut Ejersbo (dalam Siswono, 2008) dalam pembelajaran matematika masalah open ended dijelaskan sebagai berikut. 1) Prosesnya terbuka, ini berarti strategi-strategi berbeda dapat dipilih untuk dapat memecahkan masalah, 2) Produk akhirnya terbuka, seperti beberapa hasil yang bernilai benar dapat dipilih untuk memecahkan masalah, 3) Cara 
untuk memformulasikan masalah terbuka, yang artinya pertayaan atau masalah dapat dilakukan sendiri.

Field dependent (FD) dan field independent (FI) merupakan gaya kognitif menurut Witkin (1977). Perbedaan mendasar antara keduanya yakni dalam hal melihat suatu permasalahan. Individu FI lebih analitis dibandingkan dengan individu FD yang mengatasi masalah dengan cara global namun mampu menangani efek pengecoh. Ciri dasar tersebut bisa di aplikasikan pada penelitian yang melibatkan individu berpikir kritis dalam memecahkan masalah.

Berpikir kritis dapat dikembangkan salah satunya dengan pembelajaran matematika (Ismail, dkk, 2018). Berdasarkan pada penelitian Pradika dan Murwaningsih (2012), menyatakan bahwa dalam menyelesaikan masalah geometri siswa SMP masih banyak yang melakukan kesalahan. Sehingga penelitian ini menggunakan masalah open ended dengan materi segitiga.

Berdasarkan pada penjabaran di atas, penelitian ini bertujuan untuk memberikan gambaran profil berpikir kritis siswa dengan gaya kognitif FI dan FD dalam memecahkan masalah open ended matematika.

\section{Metode}

Penelitian ini termasuk penelitian deskriptif kualitatif dengan tujuan memberikan gambaran mengenai profil berpikir kritis siswa dalam memecahkan masalah matematika open ended ditinjau dari gaya kognitif field dependentindependent.

Penelitian ini menggunakan subjek 2 siswa kelas IX SMP dengan rincian masing-masing 1 siswa gaya kognitif FD dan FI dengan kriteria siwa yang komunikatif. Pemilihan subjek dilakukan dengan teknik memberikan lembar GEFT (Group Embedded figure Test) yang bertujuan mengetahui subjek bergaya kognitif FD atau FI. Selanjutnya pemberian lembar tes pemecahan masalah open ended (TPMOE). Setelah dilakukannya GEFT dan TPMOE, dipilih 1 siswa dengan gaya kognitif FD dan 1 siswa FI yang komunikatif dan memenuhi indikator terbanyak dalam memecahkan masalah untuk melakukan wawancara. Wawancara dilakukan untuk mendapatkan penjelasan mendetail yang tidak tertera pada lembar jawaban yang menyangkut dengan indikator berpikir kritis. Teknik analisis data dilakukan berdasarkan indikator yang tertera pada tabel 2 .

Tabel 2. Indikator kriteria berpikir kritis dalam langkah pemecahan masalah

\begin{tabular}{|l|l|l|}
\hline \multicolumn{1}{|c|}{$\begin{array}{c}\text { Langkah } \\
\text { Pemecahan } \\
\text { Masalah }\end{array}$} & \multicolumn{1}{c|}{$\begin{array}{c}\text { Kriteria } \\
\text { Berpikir Kritis }\end{array}$} & \multicolumn{1}{c|}{ Indikator } \\
\hline $\begin{array}{l}\text { Memahami } \\
\text { masalah }\end{array}$ & Klarifikasi & $\begin{array}{l}\text { Menyebutkan informasi yang diketahui dan yang } \\
\text { ditanya dalam permasalahan. }\end{array}$ \\
\cline { 3 - 3 } & Menyebutkan hubungan antar bagian yang berbeda. \\
\cline { 3 - 3 } & $\begin{array}{l}\text { Menyebutkan informasi yang relevan dan yang tidak } \\
\text { relevan. }\end{array}$ \\
\hline $\begin{array}{l}\text { Menyusun } \\
\text { rencana }\end{array}$ & Asesmen & $\begin{array}{l}\text { Memberikan alasan logis terhadap pemilihan informasi } \\
\text { relevan yang digunakan dalam memecahkan masalah. }\end{array}$ \\
\cline { 3 - 4 } & $\begin{array}{l}\text { Memberikan alasan logis terkait dengan strategi yang } \\
\text { digunakan. }\end{array}$ \\
\cline { 3 - 4 } & $\begin{array}{l}\text { Dapat menilai kebenaran dan memberikan alasan yang } \\
\text { tepat pada setiap langkah pengerjaan. }\end{array}$ \\
\cline { 3 - 4 } & Strategi & $\begin{array}{l}\text { Mengusulkan langkah-langkah spesifik yang mengarah } \\
\text { pada solusi. }\end{array}$ \\
\cline { 3 - 4 } & $\begin{array}{l}\text { Memprediksi hasil dari langkah-langkah yang telah } \\
\text { disusun. }\end{array}$ \\
\cline { 3 - 4 } $\begin{array}{l}\text { Melaksanakan } \\
\text { rencana }\end{array}$ & Inferensi & Memecahkan masalah sesuai rencana dengan tepat \\
\hline $\begin{array}{l}\text { Memeriksa } \\
\text { kembali }\end{array}$ & Strategi & Mengevaluasi langkah yang mungkin \\
\hline
\end{tabular}

Dari hasil analisis data GEFT, TPMOE, dan wawancara akan dideskripsikan profil berpikir kritis siswa dalam memecahkan masalah matematika open ended ditinjau dari gaya kognitif.

\section{Hasil dan Pembahasan}

1. Subjek Field Dependent (SFD)

Subjek field dependent dapat menjawab permasalahan menggunakan dua cara. Namun hanya satu cara saja yang dijawab dengan 
tepat baik pada langkah penyelesaian maupun pada hasil akhirnya. Berikut hasil pengerjaan soal open ended oleh SFD.

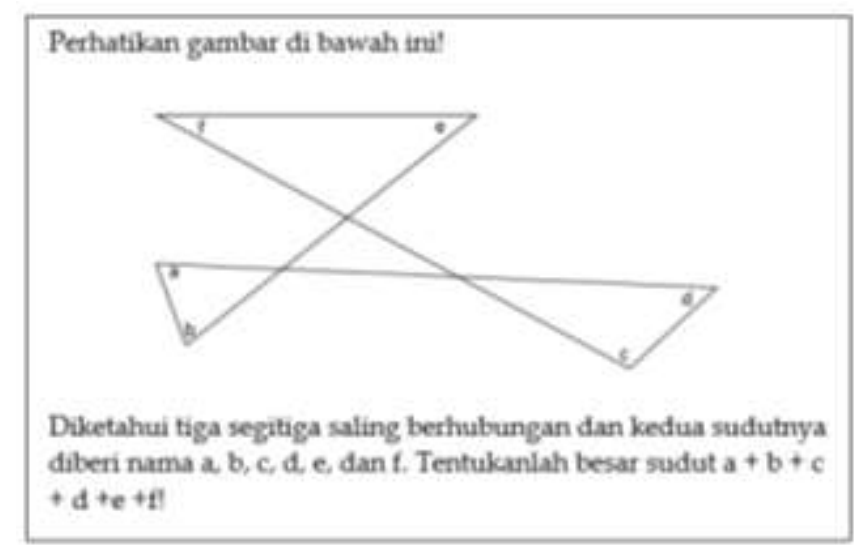

Gambar 1. Soal open ended yang digunakan dalam penelitian

Dua subjek penelitian SFD dan SFI dapat menjawab permasalahan menggunakan dua cara. Berikut akan dijelaskan mengenai hasil dan pembahasan yang diperoleh.

1. Subjek Field Dependent (SFD)
Subjek field dependent dapat menjawab permasalahan menggunakan dua cara. Namun hanya satu cara saja yang dijawab dengan tepat baik pada langkah penyelesaian maupun pada hasil akhirnya. Berikut hasil pengerjaan soal open ended oleh SFD.

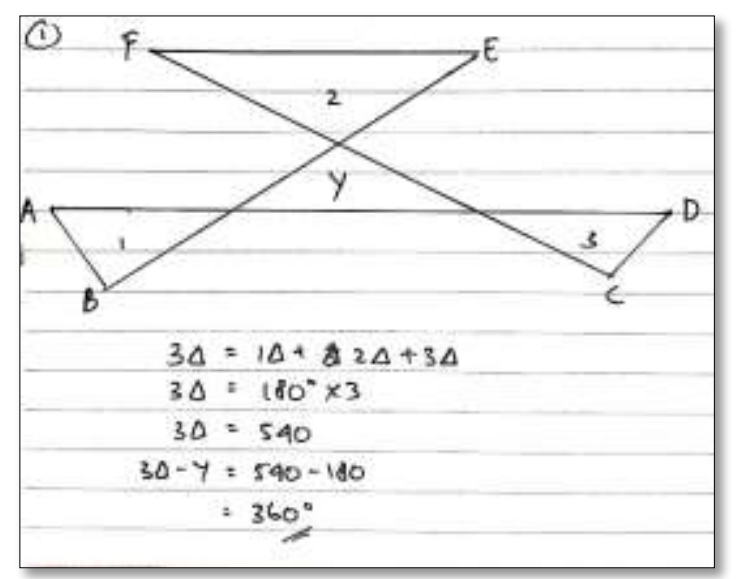

Gambar 2. Hasil pengerjaan SFD cara I dalam memecahkan masalah open ended.

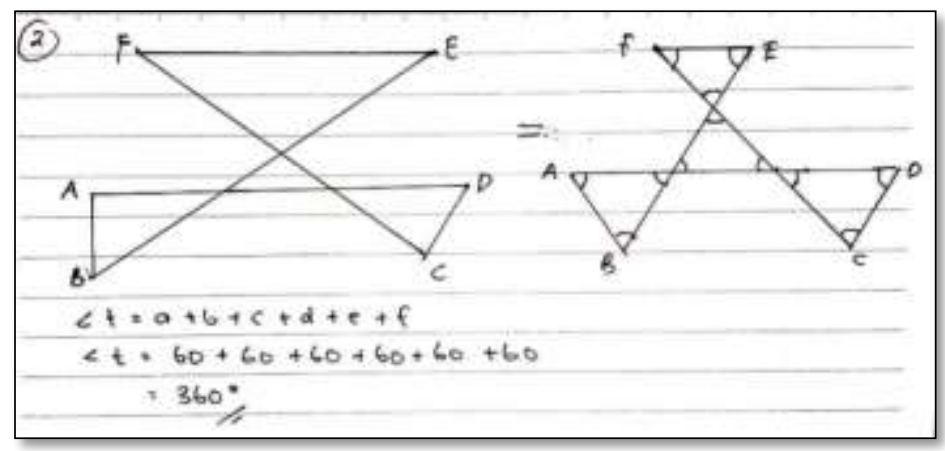

Gambar 3. Hasil pengerjaan SFD cara II dalam memecahkan masalah open ended.

Berdasar pada analisis hasil penelitian terkait dengan berpikir kritis untuk SFD dapat menyebutkan yang diketahui dan yang ditanyakan soal pada langkah memahami masalah. Namun pada saat menyebutkan yang diketahui dalam soal terdapat kesalahan dalam memahami soal karena SFD terpengaruh oleh gambar yang menyerupai garis sejajar 
sehingga hanya dapat menyelesaikan dengan satu cara yang tepat. Dalam membedakan stimulus melalui situasi, individu FD mengalami kesulitan sehingga persepsinya mudah terpengaruhi (Altun \& Cakan 2006). Berbeda dengan penelitian Safi dkk (2018) yang menunjukkan bahwa SFD dapat menafsirkan masalah yang diberikan dengan baik meskipun memerlukan pembacaan soal beberapa kali. Hal ini dapat terjadi dikarenakan kemampuan setiap anak berbeda dalam memahami soal, serta ilmu yang dimiliki setiap anak juga berbeda pula. Selain itu SFD dapat menyebutkan hubungan yang saling terkait pada soal dan menyebutkan bahwa tidak terdapat informasi yang tidak terkait pada soal. Pada langkah menyusun rencana SFD memberikan alasan logis terkait dengan pemilihan informasi yang digunakan dalam menyelesaikan masalah. Kemudian SFD menyusun dua langkah penyelesaian yang akan digunakan serta subjek dapat memprediksi hasil akhir. Rencana penyelesaian yang disusun SFD dan SFI berbeda. Hal tersebut menunjukkan kedua subjek memiliki memori kerja yang berbeda yang disebabkan latar belakang pengetahuan yang berbeda. Sesuai dengan pendapat Woolfolk (2008) yang mengatakan bahwa memori kerja bersifat individual. Pada langkah melaksanakan rencana SFD melakukan perhitungan sesuai dengan langkah penyelesaian yang telah direncanakan sebelumnya. Pada langkah memeriksa kembali SFD tidak menyadari kesalahan yang telah dilakukan pada cara pengerjaan ke II meskipun SFD telah memeriksa kembali lembar jawabannya.

2. Subjek Field Independent (SFI)

Subjek field independent dapat menjawab permasalahan menggunakan dua cara dengan jelas dan benar. Berikut hasil pengerjaan soal open ended oleh SFI.

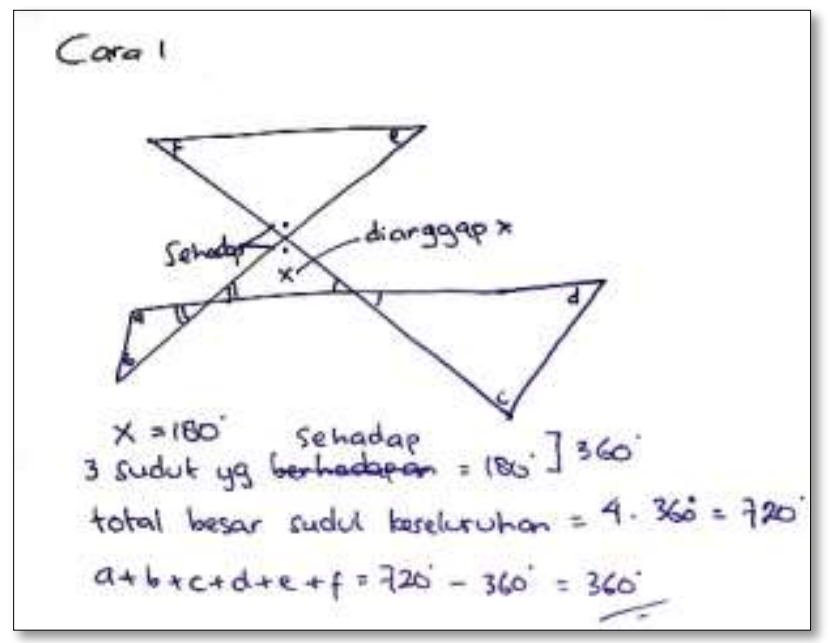

Gambar 4. Hasil pengerjaan SFI cara I dalam memecahkan masalah open ended.

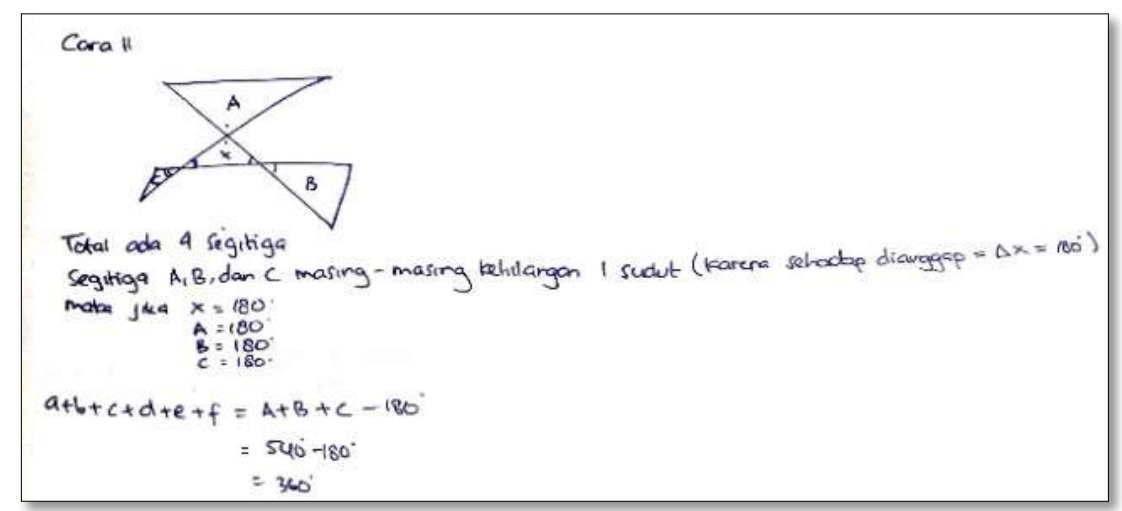

Gambar 5. Hasil pengerjaan SFI cara II dalam memecahkan masalah open ended.

Berdasarkan analisis hasil penelitian terkait dengan berpikir kritis untuk SFI bisa menyebutkan yang diketahui pada soal. Serta bisa menyebutkan yang ditanya soal yang 
tertera dengan benar pada langkah memahami masalah dikarenakan SFI dapat mengorganisirkan dengan baik. Sesuai dengan pendapat Andriyani (2018) bahwa SFI dapat mengorganisirkan objek dengan baik. SFI tidak terpengaruh oleh gambar soal yang terlihat seperti garis sejajar. Riding \& Cheema (Guisande et al, 2007) menyatakan bahwa SFI memilih secara seletif dalam menyerap informasi yang diterimanya. Selain itu SFI dapat menyebutkan hubungan yang saling terkait pada soal dan menyebutkan bahwa tidak terdapat informasi yang tidak terkait pada soal. SFI lebih baik daripada SFD dalam memahami masalah (Ngilawajan, 2013). Pada langkah menyusun rencana SFI memberikan alasan logis terkait dengan pemilihan informasi yang digunakan dalam menyelesaikan masalah. Kemudian SFI menyusun dua langkah penyelesaian yang akan digunakan serta subjek dapat memprediksi hasil akhir. SFI dapat menyusun tahapan penyelesaian dan memecahkan masalah dengan tepat dikarenakan SFI mampu mengorganisir informasi yang diperolehnya dengan baik (Tisngati, 2015). Pada langkah melaksanakan rencana SFI memecahkan masalah sesuai dengan langkah penyelesaian yang telah direncanakan sebelumnya. Pada langkah memeriksa kembali SFI melakukan pengecekan kembali lembar jawaban. SFI memperoleh hasil yang sama dengan dua cara yang berbeda dengan tepat.

\section{Simpulan}

Berlandaskan hasil dari analisis data dan pembahasan yang telah dijabarkan, dapat disimpulkan sebagai berikut.

1. Profil berpikir kritis siswa SMP field dependent (FD) dalam memecahkan masalah matematika open ended.

SFD dapat menyebutkan informasi yang diketahui pada langkah memahami masalah. Selain itu subjek juga menyebutkan mengenai apa yang ditanyakan pada soal serta menyebutkan informasi yang terkait dan yang tidak terkait meskipun terdapat kesalahan dalam menyebutkan informasi yang diketahui pada soal. SFD terpengaruh dengan gambar yang menyerupai garis sejajar sehingga hanya dapat menyelesaikan dengan satu cara yang tepat. Hal tersebut merupakan kesalahan fatal sebab kesalahan terjadi saat memahami masalah sehingga menyebabkan langkah penyelesaian selanjutnya terpengaruhi. Pada langkah ini SFD memenuhi 2 dari 3 indikator berpikir kritis klarifikasi. Pada langkah menyusun rencana, SFD memberikan alasan masuk akal terkait dengan strategi yang dipakai, memilih informasi yang terkait dengan pemecahan masalah, serta dapat memberikan alasan yang tepat pada setiap langkah. SFD juga dapat memperkirakan hasil dari langkah pengerjaan yang telah direncanakan. Langkah ini SFD dapat memenuhi semua indikator berpikir kritis asesmen dan strategi. Pada langkah melaksanakan rencana, SFD dapat memenuhi indikator berpikir kritis inferensi. SFD menyelesaikan permasalahan sesuai dengan tahapan yang sudah direncanakan serta dapat membuat kesimpulan yang tepat. Pada langkah memeriksa kembali, SFD dapat memenuhi indikator berpikir kritis strategi. SFD memeriksa kembali langkah yang telah dikerjakan. SFD melakukan kesalahan saat memahami soal sehingga berakibat pada cara II SFD mengerjakan dengan langkah yang salah.

2. Profil berpikir kritis siswa SMP field independent (FI) dalam memecahkan masalah matematika open ended.

SFI memenuhi semua indikator berpikir kritis klarifikasi pada langkah memahami masalah. SFI dapat menyebutkan informasi yang diketahui dan yang ditanya dalam soal, menyebutkan hubungan antar bagian yang berbeda serta menyebutkan informasi yang terkait dan yang tidak terkait. Pada langkah menyusun rencana, SFI memenuhi indikator asesmen dan strategi. SFI menjelaskan alasan yang masuk akal terkait dengan strategi yang dipakai, memilih informasi yang terkait, serta dapat memberikan alasan yang tepat pada setiap langkah. SFI juga dapat memperkirakan hasil dari langkah pengerjaan yang telah direncanakan. SFI memenuhi indikator inferensi pada langkah melaksanakan rencana. SFI menyelesaikan permasalahan sesuai dengan tahap yang telah dirancang serta dapat membuat simpulan yang tepat. Pada langkah memeriksa kembali, SFI dapat memenuhi indikator berpikir kritis strategi. SFI memeriksa kembali langkah yang telah dilakukan. SFI melakukan semua tahap memecahkan masalah Polya dan kriteria berpikir kritis Jacob dan Sam. Dari penjabaran di atas dapat ditarik kesimpulan SFI lebih baik dalam memecahkan masalah matematika open ended dibandingkan dengan SFD. 


\section{Daftar Pustaka}

Al-Absi, M. (2013). The Effect of Open Ended Task-as an Assesment Tool on Fourth Grader's Mathematics Achievment, And Assesing Students Prespectives about it. Jordan journal of Educational Sciences, 9 (3), 345-351.

Altun, A., \& Cakan, M. (2006). Undergraduate Students' Academic Achievement, Field Dependent/Independent Cognitive Styles and Attitude toward Computers. Educational Technology \& Society, 9 (1), 289-297.

Andriyani, Astri. (2018). Analisis Kesalahan Siswa dalam Menyelesaikan Soal Cerita pada Materi Program Linear Ditinjau dari Gaya Kognitif Siswa. Pendekar Jurnal Pendidikan Berkarakter, 1 (1), 16-22.

Cahyani, Hesti dan Ririn Wahyu S. (2016). Pentingnya Peningkatan Kemampuan Pemecahan Masalah melalui PBL untuk Mempersiapkan Generasi Unggul Menghadapi MEA. (Online),

(https://journal.unnes.ac.id/sju/index.php/prism a/article/view/21635).

Cahyono, Budi. (2017). Analisis Keterampilan Berpikir Kritis dalam Memecahkan Masalah Ditinjau Perbedaan Gender. Jurnal Aksioma, (1), 50-64.

Guisande, Adeline. M. et al. (2007). Field Dependence-Independence (FDI) Cognitive Style: An Analysis of Attentional Functioning. Psichothema, 19, 572-577.

Ismail, dkk. (2018). Critical thinking skills of junior high school female students with high mathematical skills in solving contextual and formal mathematical problems. Journal of Physics: Conference Series.

Ngilawajan, Darma Andreas. (2013). Proses Berpikir Siswa dalam Memecahkan Masalah Matematika Materi Turunan Ditinjau dari Gaya Kognitif Field Dependent dan Field Independent. (Online), (http://ojs.umsida.ac.id/index.php/pedagogia/ar ticle/view/48/54, diakses 28 Juni 2020)
Polya, G. (2004). How to Solve it: A new Aspect of Mathematical Method. 2nd ed. New Jersey: Princenton University Press.

Prihartini E, Lestari P, Saputri S. A. (2018). Meningkatkan Kemampuan Berpikir Kritis Matematis Menggunakan Pendekatan Open Ended. (Online), (https://journal.unnes.ac.id/sju/index.php/prism a/article/download/21427/10176/, diakses 2 Februari 2020).

Rasiman \& Pramasdyahsari, A. S. (2014). Development of Mathematics Learning Media E-Comic Based on Flip Book Maker to Increase the Critical Thinking Skill and Character of Junior High School Students. International Journal of Education Research, 2 (11), 535-544.

Safi Harisa, dkk. (2018). Berpikir Kritis dalam Pemecahan Masalah Aljabar Linear I Ditinjau dari Kemampuan Awal dan Gaya Kognitif pada Mahasiswa S1 Progrm Studi Pendidikan Matematika Universitas Negeri Makasar. Online, http://eprints.unm.ac.id/11559/1/ARTIKEL.p $d f$.

Setiawan, Hilmi. (2019). Ranking PISA Indonesia Turun, Dipicu Salah Orientasi Pendidikan. Dalam Jawa Pos, 4 Desember 2019. (https://www.jawapos.com/nasional/pendidika n/04/12/2019/ranking-pisa-indonesia-turundipicu-salah-orientasi-pendidikan/)

Siswono, Tatag Y. E. (2008). Model Pembelajaran Matematika Berbasis Pengajuan Masalah untuk Meningkatkan Kemampuan Berpikir Kreatif. Surabaya: Unesa University Press.

Tisngati, U. (2015). Proses Berpikir Reflektif Mahasiswa dalam Pemecahan Masalah pada Materi Himpunan Ditinjau dari Gaya Kognitif Berdasarkan Langkah Polya. Beta Jurnal Tadris Matematika, 8 (2), 115-124.

Witkin, H. A. dan D. R. Goodenough. (1977). Field Dependence and Interpersonal Behavior. Psychological Bulletin, 84, 661-689.

Woolfolk, A. (2008). Educational Psychology (10th ed). Boston, MA: Allyn \& Bacon. 